POLLACK PERIODICA

An International Journal for Engineering and Information Sciences

DOI: $10.1556 / 606.2016 .11 .1 .9$

Vol. 11, No. 1, pp. 91-100 (2016)

www.akademiai.com

\title{
VENTILATION INTENSITY IN A HIGH-RISE BUILDING AFTER COMPLETE RETROFIT OF ITS ENVELOPE
}

\author{
${ }^{1}$ Michal KRAJČÍK, ${ }^{2}$ Ján TAKÁCS \\ ${ }^{1,2}$ Faculty of Civil Engineering, Slovak University of Technology in Bratislava \\ Radlinského 11, 81005 Bratislava, Slovakia \\ e-mail: ${ }^{1}$ michal.krajcik@gmail.com, ${ }^{2}$ jan.takacs@stuba.sk
}

Received 9 July 2015; accepted 9 October 2015

\begin{abstract}
Retrofit of the old building stock presents a good possibility to reduce the energy consumption. However, as the envelopes of old buildings become tighter, a risk increases that the fresh outside air supplied to the indoor environment by natural infiltration can decrease below the amounts required for a comfortable indoor environment, especially in buildings where mechanical ventilation has not been installed. This study presents an efficient method to measure the ventilation intensity, demonstrated on a 40 -years old high-rise office building after a complete envelope retrofit. The well-established tracer gas decay and tracer gas step-up method were employed to obtain the ventilation intensity, using the natural $\mathrm{CO}_{2}$ produced by the occupants as the tracer gas. The measured values of the air change rate were between 0.1 and $0.7 \mathrm{l} / \mathrm{h}$ for the simple façade, whereas it ranged from 0.2 to $0.51 / \mathrm{h}$ for the double skin façade, with the windows closed. The level of compliance with ventilation requirements varied, depending on the standard and the philosophy adopted.
\end{abstract}

Keywords: $\mathrm{CO}_{2}$ concentration, Tracer gas, Air quality, Air change rate, High-rise building

\section{Introduction}

With regard to the enormous potential of energy savings for buildings, gradual strengthening of the requirements on the level of energy performance has been in progress in the EU [1]. In Central Europe, the major part of buildings energy is consumed for space heating, and better energy performance shall be achieved to large extent by decreasing the heat losses by transmission by thermal insulation, and by decreasing the heat losses by infiltration by tightening the building envelope. However, the subsequent reduction of the natural infiltration of the fresh outside air, which is still 
being used as the main mean of ventilation in most buildings, results in deteriorated indoor air quality, and the amount of the fresh outside air supplied indoors may not comply with the requirements on the air quality in buildings. The present study demonstrates the possibility to measure the ventilation intensity indirectly; using the natural $\mathrm{CO}_{2}$ produced by the occupants as the tracer gas, and shows an application of this method in a new high-rise building with a new energy efficient envelope.

\section{Envelope of the high-rise building}

The high rise building investigated in this study is the office building of the Faculty of Civil Engineering, Slovak University of Technology in Bratislava (Fig. 1). With respect to the poor physical and thermo-physical conditions of the original 40-year old façade, complete retrofit of the façade was carried out recently.

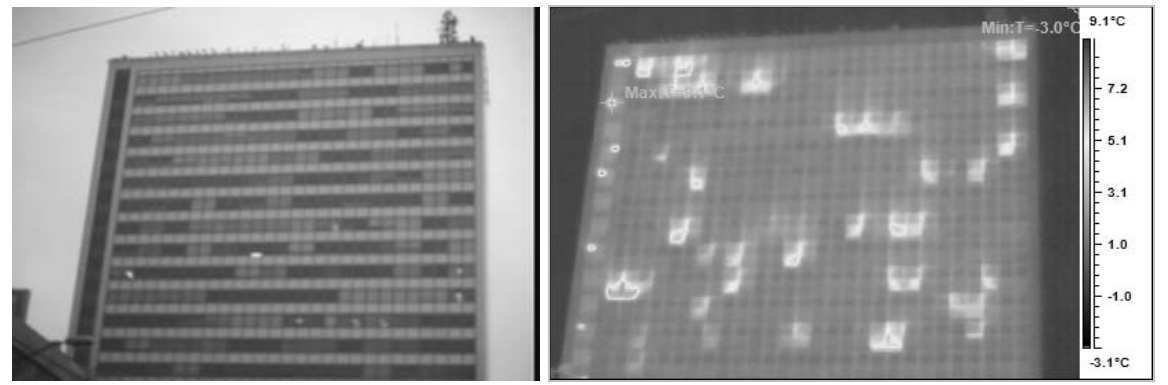

Fig. 1. View and infrared image of the double skin facade, facing South-East. The spots in the infrared image are caused by opening the inner windows into the gap between the two skins, Photo: Michal Lukačovič

On the North-West, the new façade is simple, with triple glazing and the possibility to open the windows to the exterior, whereas on the South-East it is a double skin façade, with a gap between the two windows, not providing any possibility to open the window directly to the exterior, but only to the gap (Fig. 2). Within the gap, the outside fresh air is allowed to flow, accessing the gap by openings in the façade. Both façade types contain blinds, which are installed on the inner window surface in the case of the simple façade, and in the gap between the windows in the case of the double skin façade.

\section{Measurement location and measuring instruments}

Two offices on the $6^{\text {th }}$ floor, one with the simple and one with the double skin façade, and two offices on the $14^{\text {th }}$ floor, one with the simple and one with the double skin façade, were investigated. The measuring device was a data logger, monitoring the room air temperature, relative air humidity and the $\mathrm{CO}_{2}$ concentration. The loggers were installed in the selected offices at the working desk. For example, the location of the logger in the office C14/6 is in Fig. 3. 


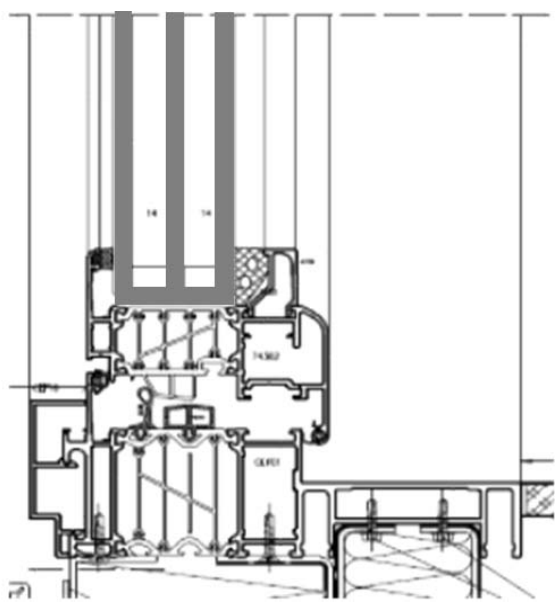

a)

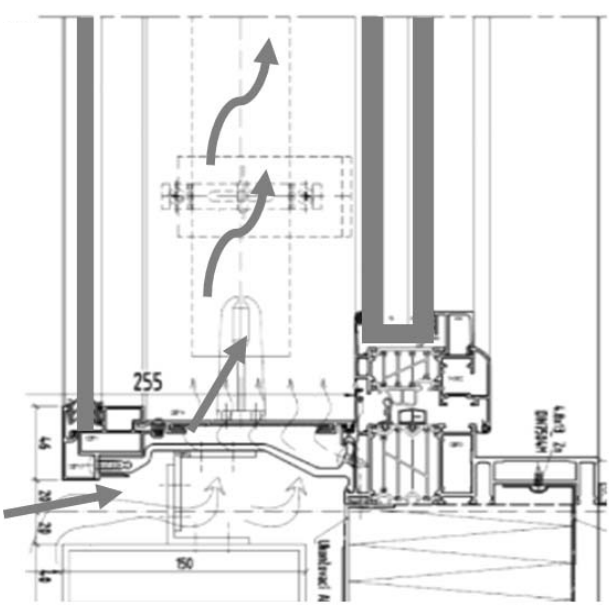

b)

Fig. 2. a) simple façade facing North-West, b) double skin façade facing South-East
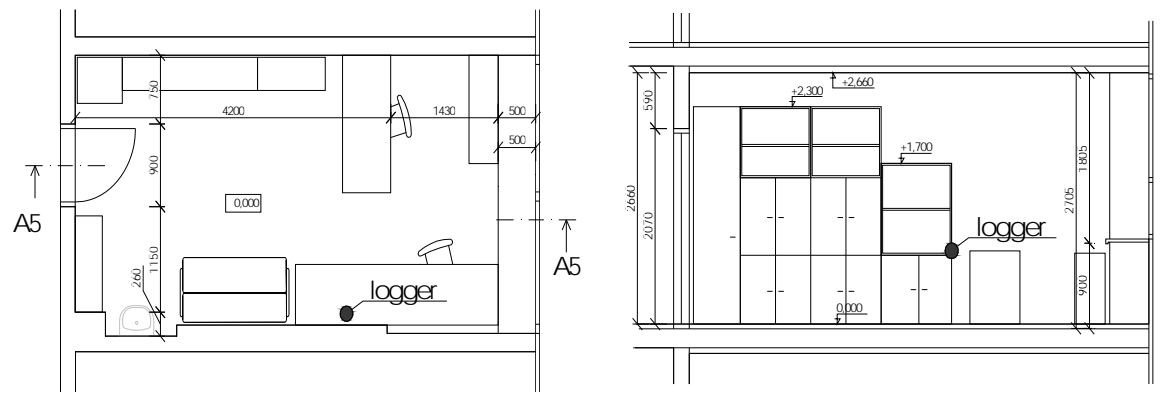

Fig. 3. Plan (left) and cross section (right) of the office C14/6 with the location of the data logger

Table I shows some of the characteristics of the offices considered in this study, relevant for the calculation of the ventilation requirements.

Table I

Some of the characteristics of the offices

\begin{tabular}{|c|c|c|c|c|c|c|}
\hline \multirow{2}{*}{ Office no. } & \multirow{2}{*}{ Facade } & \multirow{2}{*}{$\begin{array}{c}\text { No. of } \\
\text { occupants }\end{array}$} & Area & Volume & \multirow{2}{*}{ PCs } & \multirow{2}{*}{ Carpet } \\
\hline & & & $\mathrm{m}^{2}$ & $\mathrm{~m}^{3}$ & & \\
\hline C6/9 & double & 1 & 16.5 & 44 & 1 & yes \\
\hline $\mathrm{C} 6 / 20$ & simple & 1 & 17.6 & 48 & 1 & yes \\
\hline $\mathrm{C} 14 / 6$ & double & 1 & 18.3 & 49 & 1 & yes \\
\hline C14/19 & simple & 2 & 17.8 & 48 & $2 *$ & yes \\
\hline
\end{tabular}

* One PC and one laptop. For simplification, the sensory pollution load was assumed equal for both. 


\section{Ventilation requirements}

The required ventilation rates depend on the emission rates from pollution sources, on the requirements for acceptable indoor air quality based on health, comfort and performance, and on the philosophy adopted. An example of a difference in the philosophy adopted by different standards are the required ventilation rates prescribed by the European standard EN 15251 (2007) [2] and the American standard ASHRAE 62.1 (2007) [3]. While the ASHRAE requirements are based on perception of adapted people, the European requirements are for un-adapted people. The ventilation requirements are typically defined as the required fresh air supply in liters per second, $\mathrm{m}^{3}$ per hour, or as a number of air changes per hour. However, it is also possible to set the criteria as the maximum limit on the concentration of $\mathrm{CO}_{2}$ indoors above the outdoor $\mathrm{CO}_{2}$ concentration in ppm, or as the desired perceived indoor air quality in decipol [4]. The ventilation requirements, based on comfort criteria, as defined in different standards are shown in Table II, presented as the number of air changes per hour. The ventilation criteria for comfort are stricter than the ventilation criteria for health, thus it is assumed that when the comfort criteria are satisfied, the criteria on health are also satisfied.

\section{Methodology of the infiltration measurements}

The infiltration airflows were expressed as the air change rate, and were measured by tracer gas measurements. In these measurements, $\mathrm{CO}_{2}$ was used as the natural tracer gas produced by the occupants. Two methods were used. The tracer gas step-up method, when the air change rate was calculated from the increasing $\mathrm{CO}_{2}$ concentration due to the $\mathrm{CO}_{2}$ produced by the occupants, and the tracer gas decay method, from the decreasing $\mathrm{CO}_{2}$ concentration, when the occupants had left the room. A specifically designed questionnaire was distributed to the occupants to help interpreting the results of the $\mathrm{CO}_{2}$ concentration. In the tracer gas step-up method, the ventilation intensity was calculated using the following equation:

$$
C_{i}(t)=\left(C_{0}-C_{a}\right) \cdot e^{-\lambda \cdot t_{i}}+C_{a}+\frac{E}{\lambda \cdot V_{R}\left(1-e^{-\lambda \cdot t_{i}}\right)},
$$

where $C_{0}$ is the tracer gas concentration at the beginning on the measurement $\left(\mathrm{kg} / \mathrm{m}^{3}\right)$; $C_{a}$ is the tracer gas concentration outside $\left(\mathrm{kg} / \mathrm{m}^{3}\right) ; \lambda$ is the air change rate $(1 / \mathrm{h}) ; E$ is the amount of tracer gas emitted per unit time $\left(\mathrm{m}^{3} / \mathrm{s}\right) ; V_{R}$ is the volume of the room $\left(\mathrm{m}^{3}\right) ; t_{i}$ is the time $(\mathrm{h})$.

In the tracer gas step-up method, the room volume $V_{R}$, the tracer gas concentration outside $C_{a}$, the tracer gas concentration at the beginning of the measurement $C_{0}$ and the time $t_{i}$ are known. When $\mathrm{CO}_{2}$ is used as the tracer gas, the amount of $\mathrm{CO}_{2}$ emitted by occupants can be estimated [5], [6]: 


$$
E=\frac{R Q \cdot 0.00276 M \cdot 0.203 H^{0.725} \cdot W^{0.425}}{0.23 \cdot R Q+0.77}
$$

where $R Q$ is the respiratory quotient, i.e. the relative volumetric rates of carbon dioxide produced to oxygen consumed. The value of $R Q$ depends on diet, level of physical activity, physical condition and is equal to 0.83 for an adult of average size engaged in light or sedentary activities; $M$ is the level of physical activity in met; $H$ is the body height $(\mathrm{m}) ; W$ is the body mass $(\mathrm{kg})$.

Table II

Ventilation requirements for single offices based on different standards, in air change rates $\left(\mathrm{h}^{-1}\right)$

\begin{tabular}{|c|c|c|c|c|c|}
\hline \multirow{2}{*}{ Calculation method } & \multirow{2}{*}{ Requirements } & \multicolumn{4}{|c|}{$\begin{array}{l}\text { Office / Ventilation } \\
\text { requirement }\end{array}$} \\
\hline & & $\mathrm{C} 6 / 9$ & $\mathrm{C} 6 / 20$ & $\mathrm{C} 14 / 6$ & $\mathrm{C} 14 / 19$ \\
\hline $\begin{array}{l}\text { CR 1752 (1998) } \\
\text { Pollution from occupants, } \\
\text { unadapted people }\end{array}$ & $\begin{array}{l}\text { category } \mathrm{B}(20 \% \\
\text { dissatisfied }) \\
\mathrm{CO}_{2} \text { concentration indoors } \\
\text { less than } 660 \mathrm{ppm} \text { above the } \\
\text { outdoor } \mathrm{CO}_{2} \text { concentration } \\
\text { level }\end{array}$ & 0.6 & 0.6 & 0.6 & 1.1 \\
\hline $\begin{array}{l}\text { CR } 1752 \text { (1998) } \\
\text { Total pollution load, } \\
\text { unadapted people }\end{array}$ & $\begin{array}{l}\text { category B }(20 \% \\
\text { dissatisfied) desired } \\
\text { perceived indoor air quality } \\
\text { of } 1.4 \text { decipol }\end{array}$ & 2.6 & 2.5 & 2.5 & 3.3 \\
\hline $\begin{array}{l}\text { EN } 15251 \text { (2007) } \\
\text { Total pollution load, } \\
\text { low polluting building, } \\
\text { unadapted people }\end{array}$ & $\begin{array}{l}\text { category II }(20 \% \\
\text { dissatisfied) ventilation rate } \\
\text { of } 71 / \text { (s.person) and } 0.7 \\
1 /\left(\mathrm{s} . \mathrm{m}^{2}{ }_{\text {floor }}\right)\end{array}$ & 1.5 & 1.5 & 1.5 & 2.0 \\
\hline $\begin{array}{l}\text { EN } 15251(2007) \\
\text { Total pollution load, } \\
\text { non low polluting building, } \\
\text { unadapted people }\end{array}$ & $\begin{array}{l}\text { category II }(20 \% \\
\text { dissatisfied) ventilation rate } \\
\text { of } 71 /(\text { s.person) and } 1.4 \\
1 /\left(\mathrm{s} . \mathrm{m}_{\text {floor }}^{2}\right)\end{array}$ & 2.5 & 2.4 & 2.4 & 2.9 \\
\hline $\begin{array}{l}\text { ASHRAE } 62.1 \text { (2013) } \\
\text { Total pollution load, } \\
\text { adapted people }\end{array}$ & $\begin{array}{l}20 \% \text { dissatisfied } \\
\text { ventilation rate of } 2.5 \\
1 /(\text { s.person }) \text { and } 0.3 \\
1 /\left(\mathrm{s}^{2} \mathrm{~m}_{\text {floor }}\right)\end{array}$ & 0.6 & 0.6 & 0.6 & 0.8 \\
\hline
\end{tabular}

The air change rate $\lambda$ is then iteratively adjusted so that the constructed (calculated) curve is fitted to the measured curve of the increasing $\mathrm{CO}_{2}$ concentration. When the least square curve is found, the approximated curve constructed based on (1) is adjusted to fit to the least square curve to obtain as good a match between the two curves as possible (Fig. 4). 
In the tracer gas decay method, the part of the mass balance equation involving production of the $\mathrm{CO}_{2}$ by humans vanishes, as no people are present during the decay. (2) is then simplified as follows:

$$
C_{i}(t)=\left(C_{0}-C_{a}\right) \cdot e^{-\lambda \cdot t}+C_{a}
$$

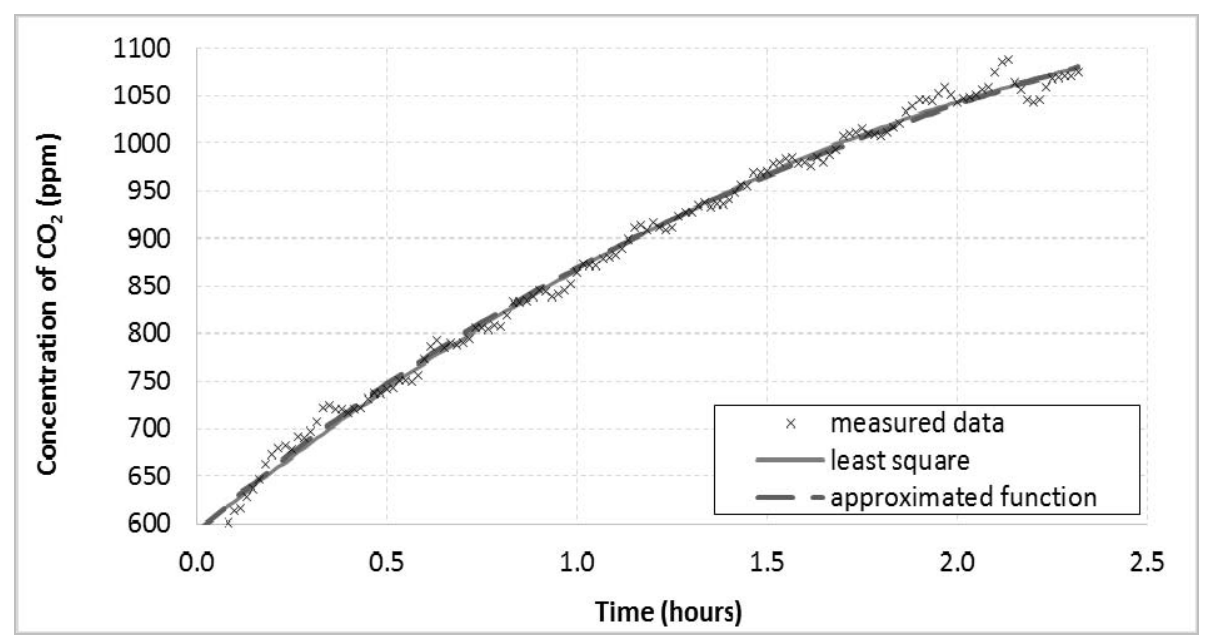

Fig. 4. Fitting of the approximated function (dashed curve) to the measured curve of increasing $\mathrm{CO}_{2}$ concentration (stars) according to the least square method (continuous curve)

The air change rate $\lambda$ is calculated from (3) iteratively. However, it is also possible to calculate the air change rate directly, using the logarithmic form:

$$
\ln \left(C(t)-C_{a}\right)=-\lambda \cdot t+\ln \left(C_{0}-C_{a}\right)
$$

From this linearized form it is possible to directly calculate the ventilation intensity $\lambda$. An example of such linearized form is shown in Fig. 5 with the least square equation.

\section{Results}

Fig. 6 shows the air change rate obtained by the tracer gas step-up method in the offices on the sixth floor $(\mathrm{C} 6 / 20)$ and on the $14^{\text {th }}$ floor $(\mathrm{C} 14 / 19)$, respectively, both with the simple façade. In the other two offices investigated in the present study, the measured data is not suitable for the application of the tracer gas step-up method. The error bars in the figure indicate absolute values of the measurements uncertainty. In the tracer gas step-up method, the uncertainty of the measurement is associated mainly with the uncertainty in the exact determination of the room volume, the outdoor $\mathrm{CO}_{2}$ concentration and the amount of $\mathrm{CO}_{2}$ produced by the occupant. Therefore, the lower confidence limit is constructed by decreasing the $\mathrm{CO}_{2}$ production by $1 \mathrm{l} / \mathrm{s}$, decreasing 
the $\mathrm{CO}_{2}$ concentration outside by $10 \mathrm{ppm}$, and by increasing the room volume by $5 \%$. Similarly, the upper confidence limit is constructed by increasing the $\mathrm{CO}_{2}$ production by $1 \mathrm{l} / \mathrm{s}$, increasing the $\mathrm{CO}_{2}$ concentration outside by $10 \mathrm{ppm}$, and by decreasing the room volume by $5 \%$. The true values of air change rate are assumed to lie within the error bars. Only measurement periods when the concentration increase was stable for at least about one and half hour were taken to account to assure that the results are reliable.

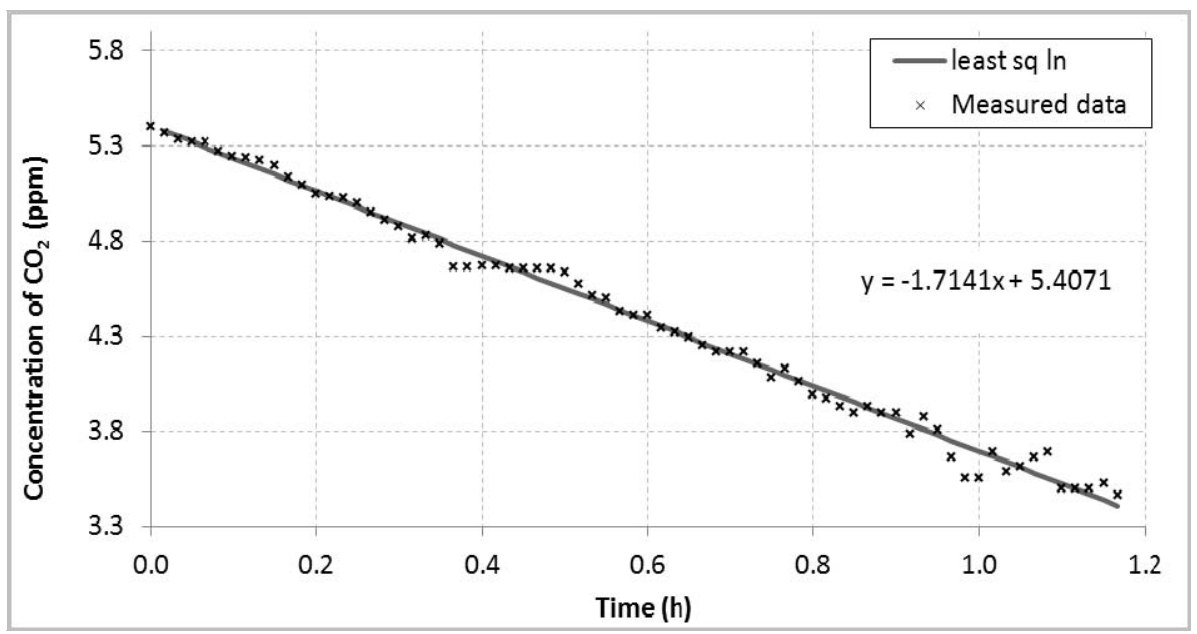

Fig. 5. Logarithmic form of the $\mathrm{CO}_{2}$ decay

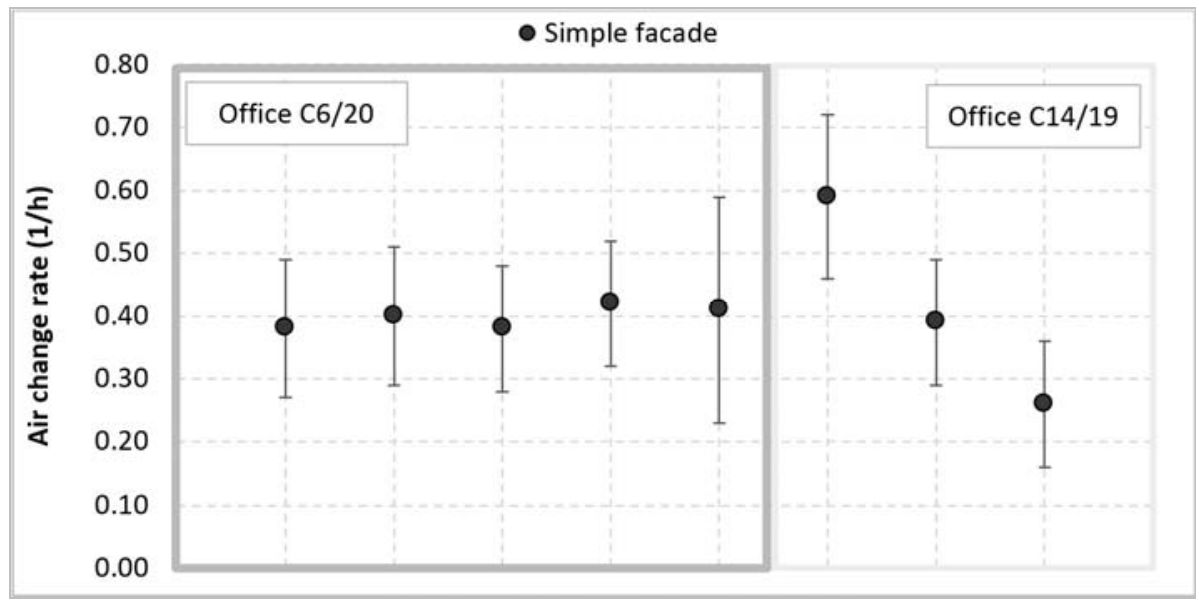

Fig. 6. Air change rate measured in two offices with simple façade by tracer gas step-up method

Besides of the tracer gas step-up method, the tracer gas decay method was used to calculate the air change rate, when the occupants had left the room and the $\mathrm{CO}_{2}$ 
concentration started to decrease. The linearized form of the tracer gas decay equation (4) was used, which allowed to calculate the air change rate directly (i.e. not by iteration). The $95 \%$ confidence interval to account for imprecise estimation of the $\mathrm{CO}_{2}$ concentration outdoors was obtained by varying the concentration by $\pm 10 \mathrm{ppm}$. The total uncertainty was obtained by adding the two uncertainties, thus the uncertainty to account for the discrepancy between the estimated value and the measured data [7], and the uncertainty due to imprecise estimation of the $\mathrm{CO}_{2}$ concentration outdoors. Graphical representation of the air change rate measured by the tracer gas decay method is in Fig. 7.

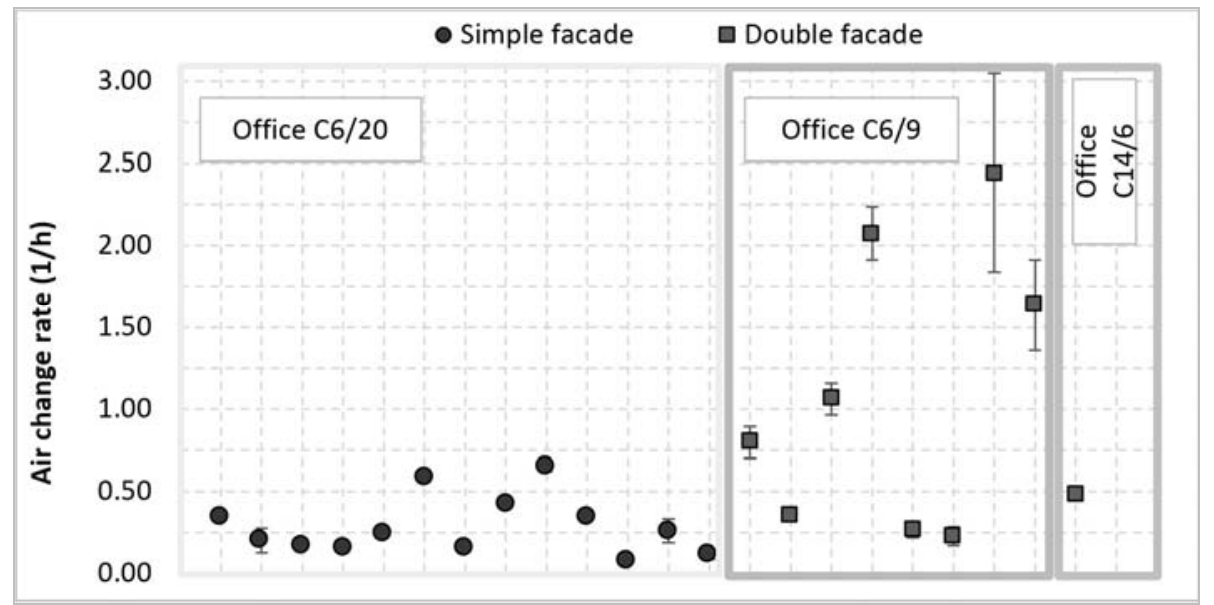

Fig. 7. Air change rate measured by tracer gas decay method

\section{Discussion}

The measured values of the air change rate for the offices with the simple façade are between 0.1 and $0.71 / \mathrm{h}$. Nearly all of these values were obtained in the same office on the sixth floor, $\mathrm{C} 6 / 20$. From the questionnaire and personal communication it was found that the windows were never open. The variation in the air change rate can be explained by changes in the pressure of the outside air on the façade (the infiltration increases in windy weather), and to lower extent by infiltration of the air from adjacent spaces to the office and uncertainty of the measurements.

For the offices with the double skin façade, the values of air change rate are more scattered. All values but one were obtained in the office on the sixth floor, C6/9. Low values of 0.2 to $0.51 / \mathrm{h}$ represent the ventilation intensity with the windows and door closed. The high values in the range from 1.6 to $2.41 / \mathrm{h}$ were probably achieved by partial opening one of the windows, and the consequently increased infiltration of the fresh air from the exterior to the room. The variation in the air change rate can be explained in the same manner as for the simple façade.

The values of air change rate obtained with windows and doors closed are lower than required for ventilation of offices. The values are closest to the requirements of 
ASHRAE 62.1 (2007) [3], based on the perception of people not adapted on the indoor air, and thus less strict than the requirements as defined in EN 15251 (2007) [2] and CR 1752 (1998) [4]. A partial solution to remediate the air quality lower than required could be removing some of the pollution sources, or to replace them with ones emitting less pollution.

\section{Conclusion}

Depending on the standard and the philosophy adopted, the requirements on the indoor air quality can vary substantially. The results of air change rate measurements confirmed that the new facade is tight, i.e. the infiltration of the outside air is low, and thereby the heat loss in cold winter conditions is decreased. However, the negative consequence of this high air tightness is the ventilation intensity lower than recommended by standards. This situation could be at least partially improved by removing the pollution sources, such as old carpet, old books, etc.

Although the concentration of $\mathrm{CO}_{2}$ in the offices was relatively low due to the low density of occupants per square meter of the floor, indicating a good air quality, the results of ventilation intensity showed that the air quality may be lower than required for a comfortable indoor environment. Although the $\mathrm{CO}_{2}$ concentration is a good air quality indicator in spaces, where people and their activities are the main source of pollution, it does not take into consideration the pollution from building materials, furniture and carpets, which are likely an important pollution source in this study. Thus, the concentration of $\mathrm{CO}_{2}$ as the indoor air quality indicator should be used with care in spaces similar to those investigated in this study.

\section{Acknowledgement}

This publication was supported by Competence Centre for SMART Technologies for Electronics and Informatics Systems and Services, ITMS 26240220072, funded by the Research \& Development Operational Programme from the ERDF. We support the research activities in Slovakia/The project is co-funded by the EU.

\section{References}

[1] Magyar Z. Buildings in the key role in the EU energy efficiency action plan, REHVA Journal, Vol. 48, 2011, pp. 86-88.

[2] EN 15251, Indoor environmental input parameters for design and assessment of energy performance of buildings addressing indoor air quality, thermal environment, lighting and acoustics, Brussels, European Committee for Standardization, 2007.

[3] ASHRAE, Ventilation for acceptable Indoor air quality, Atlanta GA, American Society of Heating, Refrigerating and Air Conditioning Engineers (ASHRAE Standard 62.1-2007), 2007.

[4] CR 1752, Ventilation for buildings, Design criteria for the Indoor environment, Brussels, European Committee for Standardization, 1998. 
[5] Persily A. K. Evaluating building IAQ and ventilation with indoor carbon dioxide, ASHRAE Transactions, Vol. 103, 1997, pp. 193-204.

[6] ASHRAE Handbook, Fundamentals, Atlanta GA, American Society of Heating, Refrigerating and Air Conditioning Engineers, 2013.

[7] ASTM, ASTM Standard E741-00 (Reapproved 2006), Standard test method for determining air change in a single zone by means of a tracer gas dilution, West Conshohocken PA, American Society for Testing and Materials, 2006. 